\title{
FOOD SECURITY AND ECONOMIC GROWTH
}

\author{
Nur Marina Abdul Manap ${ }^{1}$ \\ School of Economics, Finance and Banking (SEFB), \\ University Utara Malaysia (UUM), Malaysia \\ (Email: nurmarina@uum.edu.my) \\ Normaz Wana Ismail ${ }^{2}$ \\ Department of Economics, \\ Faculty of Economics \& Management, \\ Universiti Putra Malaysia (UPM), Malaysia \\ (Email: drnormazismail@gmail.com)
}

Accepted date: 23-03-2019

Published date: 08-07-2019

To cite this document: Manap, N. M. A., \& Ismail, N. W. (2019). Food Security and Economic Growth. International Journal of Modern Trends in Social Sciences, 2(8), 108118.

DOI: $10.35631 / \mathrm{IJMTSS} .280011$

\begin{abstract}
The world has seen continued famine, starvation and malnutrition. Starvation and malnutrition have a negative impact on health, leading to poor productivity, and thus gradually affecting overall economic growth. This paper estimates the impact of food security on the economic growth of dry-land developing countries. The objective of this study is to measures the impact of food security on economic growth directly and through poverty, life expectancy, and total employment. This study employs a dynamic panel data model known as the Generalized Method of Moments (GMM). The finding of this study has proved that food security has an impact on economic growth, especially in dry-land developing countries. This research has identified that food security has a significant positive impact on food security, as an increase in food security increases economic growth. Nonetheless, food security also has an impact on economic growth in terms of life expectancy, total employment, and poverty, whereas life expectancy and total employment with better food security have a positive impact on economic growth, reduce in poverty, achieving food security and enhancing economic growth.
\end{abstract}

Keywords: Food Security, Economic Growth, Poverty, Life Expectancy

\section{Introduction}

Food is essential for survival, but the question of whether there is enough food is available for the people of the world which is subject to population growth. Insufficiency on food intake with better nutrients will cause food security problem, labour productivity reduce, increase in hunger, decrease in life expectancy and reduce economic growth.

Food security is normally discussed with reference to food self-sufficiency and food selfreliance at the national level. Food self-sufficiency is the ability of domestic production to 
meet local consumption, particularly of staple food crops. Food self-sufficiency will save foreign exchange that can be used to purchase other agriculture commodities that cannot be produced locally. The production and growing of such food crops is done within a country, with minimum dependency on the international market to ensure that sufficient food is available to feed the local population. These activities will encourage the development of small-medium enterprises (SME). Meanwhile, countries with food self-reliance will determine their production needs based on international trade patterns. Countries that apply this concept will import staple foods from the world market when prices are lower than those of local foods. So the land will be used for other purposes, such as growing crops for biofuel as a substitute for fossil fuels. The intention of this concept is to promote market liberalization and export-oriented agriculture, along with support from strong local markets, and is achieved through improvements in physical infrastructure and credit facilities. Food security can be achieved by increasing local production and productivity, increasing food imports on a regular and assured basis, providing more jobs, increasing incomes to buy food needed, and by improving food distribution systems (FAO, 2002). Food security has a positive impact on economic growth through the reduction of poverty, increased total employment and life expectancy channel, and enhanced economic growth.

Generally, food security problems occur in dry-land developing countries. This situation occurs because of food production shortages that are caused by dry-land degradation (UNEP, 2011). The degradation of dry lands is caused by unsustainable land and water use and climate change factors. The World Health Organization (WHO) has found that land degradation is caused by extreme weather conditions such as drought, pollution from human activities, deteriorating quality of soils, and poor land utility, all of which negatively affect food production. Degradation will reduce biological productivity and have an impact on an ecosystem's ability to absorb and use rainwater. Besides that, climate change also has a huge impact on food production, especially in rain-fed African agriculture systems. This situation will cause food security problem.

Sustainability in economic growth is depending on achievement of food security. Without food security strategy, countries will bear a large portion cost to sustain food security by increasing domestic production and minimize relying on food import. Relying highly on food import will cause food security problem with high levels of chronic malnutrition, limitation in human capital development, poverty problem occur, reduced labour productivity, reduce in life expectancy and decrease economic growth. The objective of this paper is to examine the impact of food security to enhanced economic growth in dry-land developing countries.

\section{Literature Review}

The measurement of the linkages between food security and economic growth is based on research by Arcand (2001) who adopted a simple neoclassical growth model to measure malnutrition, which is a proxy for food security and economic growth. The Solow NeoClassical Growth Model is a function of technology, capital, and labour. This author has added effective labour as an input in which productivity of labour depends on nutrition level in terms of Dietary Energy Supply (DES) or prevalence of food inadequacy (PFI). The effectiveness labour equation will then be added in The Solow Neo-Classical Growth Model, and new growth models will be developed.

Besides the Solow Neo-Classical Growth Model, another growth theory relating to food security in terms of nutritional intake is the Human Capital Augmented Solow Model, which was presented by Mankiw, Romer, and Weil in 1992. The impact of nutrition is through 
human capital. The concept of human capital comes from investment in human knowledge and health, which include schooling, exercise, and enough nutrition. Knowledge and health are correlated: when humans have a good knowledge of health and are more aware of the role of proper nutrition in health, this will lead to longer life expectancies and enhanced economic growth (Brumm, 1996).

Efficiency in development and economic growth will reduce poverty, famine, and undernourishment and will achieve food security, especially in dry-land developing countries. Many studies have shown that efficiency in economic growth will have a positive impact on food security. However, food security can also have a direct or indirect impact on economic growth, but few studies have discussed this issue. Jenkins \& Scanlan (2011) conducted research on food security in less developed countries between 1970 and 1990. This research has identified six important issues related to food security: modernization, economic dependence, urban bias, neo-Malthusian population pressure, ecological evolutionary processes, and militarism. The above authors adopted a lagged panel, or a conditional change model, which is considered the best method to capture structural trends that display considerable stability over time. Moreover, some previous studies have measured food security at the macro level (Timmer, 2000). Based on this research, policy makers have made conditions for food security at the micro level in terms of households' access to food at local markets and home resources. Food security seems to have a low impact on economic growth. However, based on food security strategies, this study has focused more on Asia in terms of food price instability in the world market for rice, the rate of income distribution, and trade policy, which have had an effect on food security and economic growth.

Furthermore, the modernization of economic structures has improved food security achievements for entire societies. A strong relationship exists between food security and economic growth (Timmer, 2004). There are several strategic approaches for achieving food security. First, is the rate and distribution of economic growth, which is known as pro-poor growth, as the first component of a food security strategy. The next approach is the stabilization of food prices in general by the Asian Government to generate economic growth as a long-term strategy for achieving food security and economic growth. The third strategy is domestic price stabilization, which will increase the efficiency of the private marketing sector; this is a better strategy for economic growth. This author has focused on the Asian perspective of food security, which takes rice as a main crop commodity for this study, because, first, rice is a major food staple in Asia. Second, rice it is grown by farmers on smallholdings. Third, international rice markets are considered unstable markets that cause all Asian countries to buffer their own farmers and consumers against fluctuating world prices.

Besides that, nutritional intake also plays an important role in increasing labour productivity to enhance economic growth. Strauss (1985) has highlighted that improvements in nutrition intake will result in better nutrition and health in human bodies and enhanced decisionmaking capabilities, and will increase economic growth. Moreover, this author has claimed that better childhood nutrition will increase schooling outcomes, ensure better education, and develop labour productivity. These issues are supported by Deolalikar (1988), who found that nutrition based on the Minimum Dietary Energy Requirements (MDER) is very important in determining the level of labour productivity. According to this author's analysis, the elasticity of farm output with respect to the MDER of family workers is high. This means that better nutritional intake by workers will increase farm output and lead to enhanced economic growth. 
Furthermore, nutrition and poverty have a crucial relationship. Miller et al. (1994) found that long-term poverty causes cognitive development problems among young children. This problem is caused by deficiency in nutritional requirements and low birth weight, both of which can impact children's verbal memory, vocabulary, math and reading achievement, and lead to behavioural problems. However, these poor countries can have sufficient nutrition for developing their bodies, preventing disease, increasing productivity, and enhancing economic growth. Salehi et al. (2004) have stated that children in poverty-stricken areas could have sufficient nutrition needs if all the parents and family members concerned had an educational intervention related to food and nutrition. All parents and family members need to play their role as caregivers with care resources that will ensure their children are fed with sufficient energy and protein from simple, hygienic, and cheap foods. These practices can improve children's growth and enhance their educational performance.

Moreover, while sufficient nutrition can extend life expectancy, too much food can reduce it. Kinsella (1992) found that nutrition is very important for increasing life expectancy and reducing mortality rates. However, in developed countries, increased nutritional intake can cause obesity and reduce life expectancy due to chronic disease. Increasing the obesity problem will lead to an epidemic of diabetes and reduce life expectancy. However, in dryland developing countries, where large numbers of people have a deficient nutritional intake, increasing this intake can reduce mortality rates and increase life expectancy (Walls et al., 2012).

In conclusion, Food Production is very important for achieving food security. The Food and Agriculture Organization (FAO) has determined five important input resources for food production namely land and irrigation, labour, machinery, fertilizers, and pesticide. Previous studies show that all five inputs are very important to increase food production in dry-land developing countries. However, this study is different because this study focuses on dry-land developing countries where the geographical situation is totally different compare to other dry-land developing countries with water scarcity problem. This study wand to determine either all five inputs give a same result like dry-land developing countries or its shows differently.

Besides that, this study also focusses on the four important dimension that is adopted from United States Agency International Development (USAID) and Food and Agriculture Organization (FAO) which is to identify either food availability, accessibility, utilization and stability which is known as dimension of food security give an impact to the food security in dry-land developing countries or not. This is different on previous study analysis because the authors are not analysed based on the dimension of food security. Finally, food security is very important for generating economic growth, especially in dry-land developing countries. This study is different to previous studies because its research examines the impact of food security on economic growth and the impact of food security through the channel of poverty, total employment, and life expectancy on economic growth. Besides that, this research has determined the impact of food input resources on food production in dry-land developing countries

\section{Methodology}

Generally, panel data, which are also known as longitudinal or cross-sectional time series data, is the dataset in terms of the behaviour of entities such as countries, regions, companies, and firms observed over time. There are benefits to using panel data estimation because panel data can control all variables that cannot be observed, such as cultural factors; furthermore, 
this method will control variables that change over time but not across countries or regions. This research will employ a dynamic model, known as the Generalized Method of Moments (GMM).

The dynamic panel data has built up by Arellano \& Bond (1991), Areliano \& Boverb (1995), and Blundell \& Bond (2000). These estimators are for a situation with a small time period (T) and large entities or countries $(\mathrm{N})$ panels. Besides that, this method is for a linear functional relationship with a single independent variable that is not strictly exogenous and has fixed individual effects. The GMM estimation uses the lagged values of the levels of endogenous and predetermined variables as instruments to control the endogeneity problem. The instrument's validity and the presence of serial correlation in the residual, which would eliminate the consistency of the estimator, can be tested once the equation is estimated (Gupta et al. 2005). Arellano-Bond estimation has transformed all the regressors by differencing the Generalized Method of Moments (GMM), and it is known as Difference GMM. Generally, a dynamic panel data model is shown as

$$
y_{i t}=\alpha y_{i t-1}+\beta x_{i t}+\lambda_{i}+v_{i t}
$$

\section{Model Specification}

Few studies have been conducted to measure the effects of food security on economic growth. Most of the previous research focuses only in terms of the household; in this respect, Timmer (2000) conducted a theoretical and descriptive study. However, this study will adopt a modified model specification from Arcand (2001), a model on which this author has conducted empirical research to measure the role nutrition in the population plays in contributing to economic growth. This model specification will formally be divided into two categories. One of them measures the impact of food security on economic growth. The proxy for food security is based on Dietary Energy Supply (DES), followed by Gross Domestic Product (gdp), a variable that will be used to measure economic growth, and other variables such as Life Expectancy (le), Total Employment (te), Poverty Headcount (pov), Government Expenditure (ge), Agriculture Machinery (am), and Arable Land (al). The other category for this model specification is to measure the impact of food security on economic growth with the condition of Life Expectancy (le), Poverty (pov), and Total Employment (te). The impact of food security on economic growth was adopted from the model built by Arcand (2001). The modification of the model specification is given below as:

$$
\begin{aligned}
& \ln y_{i t}=\alpha_{0}+\vartheta \ln y_{i t-1}+\beta_{1} \ln f s_{i t}+\beta_{2} \ln l e_{i t}+\beta_{3} \ln p o v_{i t}+ \\
& \beta_{4} \ln t e_{i t}+\beta_{5} \ln g e_{i t}+\beta_{6} \ln a m_{i t}+\beta_{7} a l_{i t}+v_{i t}
\end{aligned}
$$

Where the variables for this growth model contain Gross Domestic Product (y), Food Security (fs), Life Expectancy (le), Poverty (pov), and Total Employment (te). This model has also added Government Expenditure (ge), Agriculture Machinery (am), and Arable Land (al) as control variables. Arcand (2001) has used the variables Dietary Energy Supply (DES) as a proxy for Food Security, Total Employment as Labour (te), and Total Life Expectancy at Birth as a proxy for Life Expectancy (le). Besides that, The Organization for Economic Cooperation and Development (2008) has listed agriculture machinery and arable land as essential conditions for strong economic growth. The proxy for agriculture machinery is tractors. Agriculture machinery refers to the number of wheel and crawler tractors in use for agriculture, and the variable for arable land is a proxy for the per cent of arable land in agricultural areas. These two variables are adopted from World Bank indicators. Moreover, 
according to Aschauer (1989), who has used neoclassical economic growth theory, government expenditure has played an important role in enhanced economic growth. This issue is supported by Hsies \& Kon S. Lai (1994), who found that government spending contributes in a small way to economic growth. These authors have applied the endogenous growth theory model for their analysis. Moreover, government expenditure is divided into two categories: the first is productive expenditure, where government expenditure helps boost economic growth, and the second is unproductive expenditure, where this expenditure will reduce economic growth (Devarajan et al., 1996).

Additionally, food security also has an impact on economic growth, the mediation factors being life expectancy, poverty, and total employment. Equation (2) shows the impact of food security on economic growth through the life expectancy channel.

\section{i. $\quad$ Food Security and Life Expectancy}

$$
\begin{aligned}
& \ln y_{i t}=\alpha_{0}+\ln y_{i t-1}+\beta_{1} \ln f_{i t}+\beta_{2} \ln l e_{i t}+\beta_{3} \ln p o v_{i t}+\beta_{4} \ln t e_{i t}+ \\
& \beta_{5}\left(\ln f s_{i t} \times \ln l e_{i t}\right)+\beta_{8} \ln g e_{i t}+\beta_{9} \ln a m_{i t}++v_{i t}
\end{aligned}
$$

Equation (3) shows the impact of food security on economic growth through total employment channel.

ii. Food Security and total employment

$$
\begin{aligned}
& \ln y_{i t}=\alpha_{0}+\ln y_{i t-1}+\beta_{1} \ln f s_{i t}+\beta_{2} \ln l e_{i t}+\beta_{3} \ln p o v_{i t}+\beta_{4} \ln t e_{i t} \\
& +\beta_{7}\left(\ln f_{i t} \times \ln t e_{i t}\right)+\beta_{8} \ln g e_{i t}+\beta_{9} \ln a m_{i t}+v_{i t}
\end{aligned}
$$

Equation (4) shows the impact of food security on economic growth through poverty channel.

iii. $\quad$ Food Security and poverty

$$
\begin{aligned}
& \ln y_{i t}=\alpha_{0}+\ln y_{i t-1}+\beta_{1} \ln f_{i t}+\beta_{2} \ln l e_{i t}+\beta_{3} \ln p o v_{i t}+\beta_{4} \ln t e_{i t}+ \\
& \beta_{6}\left(\ln f_{i t} \times \ln p o v_{i t}\right)+\beta_{8} \ln g e_{i t}+\beta_{9} \ln a m_{i t}+v_{i t}
\end{aligned}
$$

Sufficient nutrition will also increase productivity, increase wages, increase household purchasing power, reduce poverty, and enhance economic growth (Ramachandran, 2007). This issue is supported by the World Bank (2005) report, which shows that better nutrition intake will result in healthier human bodies and increase human productivity. Furthermore, proper nutrition intake will lead to well-nourished children, increasing their intelligence and their ability to learn in school. It will also result in increased household income, reduced poverty, and an increase in economic growth.

\section{Data Description}

The dataset in this research is a panel of observation for dry-land developing countries. The data covers 75 dry-land developing countries and annual data from 1970 to 2016. Dry-land developing countries were used as a sample to show that food security can play an important role in enhancing economic growth directly or through labour, alleviating poverty, and improving life expectancy. All datasets were obtained from the Food and Agriculture Organization Statistics (FAOSTAT), the World Bank, the World Food Programme, the 
World Development Indicator, United Nations Labour Statistical Data, and the United Nations Development Programme (UNDP).

\section{Analysis ad Discussion}

Food is very important to our bodies to develop cells and tissues, produce energy, and protect our bodies from infectious disease. Food fulfilled the basic need to sustain nutrition in the body, containing two types of nutrients known as micronutrients and macronutrients. Micronutrients comprise the vitamins and minerals that are required in small quantities, and macronutrients include carbohydrates, protein, and fat, which are needed in large amounts. Generally, efficiency in economic growth can improve food security, especially in dry-land developing countries. However, this section has reversed the basic analysis, as this study will estimate the impact of food security on the economic growth of dry-land developing countries. The analysis will be divided into two categories. The first category measured the impact of food security on economic growth, and the second measures the impact of food security with the conditions of life expectancy, total employment, and poverty on economic growth.

The analysis of the relationship between food security and economic growth will apply the Generalized Method of Moment System (GMM-SYS) to analyse the impacts of food security on economic growth. The GMM-SYS is preferable compared to GMM-DIF, because the GMM system's estimation combines a standard set of explanatory variables in the first difference with suitable lagged levels as instruments, with an additional set of explanatory variables in levels with suitable lagged first difference instruments. Table 1,2 presents the various estimation results, where SYS-GMM estimators and the Arellano-Bond test for AR (2) cannot reject the null hypothesis, and it is suitable for the estimation. All of the specifications pass the Hansen-J statistic test for Over-Identifying Restriction (OIR). This confirms that all instrument sets can be considered valid.

The analysis from Table 1 illustrates that food security significance at the 1 per cent level has a positive relationship with economic growth at a coefficient of 2.8817. This result shows that food security is very important to enhance economic growth in dry-land developing countries. These results are similar to those of the study performed by Correa \& Cummins (1970), in which achievement on food security will sustain nutritional intake and boost economic growth, especially in dry-land developing countries. Furthermore, sufficient nutritional intake can increase school attendance, increase wage rates, increase purchasing power, reduce poverty, and increase economic growth (Haddad, 2013). This analysis verifies the analysis by Johnson (1997) whereby an improvement in agriculture productivity would enhance economic growth by declining chronic malnutrition problem, reduction on nutritionrelated disabilities, increase life expectancy, and increase food security.

Table 1: Food Security and Economic Growth

\begin{tabular}{|c|c|c|c|c|}
\hline GDP Per capita & Model I & ModeI II & Model III & Model IV \\
\hline $\begin{array}{l}\text { Log GDP Per Capita Lag } \\
\qquad\left(\ln y_{i t-1}\right)\end{array}$ & $\begin{array}{c}0.7968 \\
(7.28) * * *\end{array}$ & $\begin{array}{c}0.7103 \\
(12.13)^{* * *}\end{array}$ & $\begin{array}{c}0.6577 \\
(33.78) * * *\end{array}$ & $\begin{array}{c}0.6429 \\
(29.06)^{* * *}\end{array}$ \\
\hline Log Dietary Energy Supply $\left(\ln f s_{i t}\right)$ & $\begin{array}{c}2.8817 \\
(2.45)^{* * *}\end{array}$ & $\begin{array}{c}3.6393 \\
(7.12)^{* * *}\end{array}$ & $\begin{array}{c}3.5344 \\
(25.86)^{* * *}\end{array}$ & $\begin{array}{c}3.769 \\
(30.60)^{* * *}\end{array}$ \\
\hline $\begin{array}{l}\text { Log Life Expectancy at Birth } \\
\left(\ln l e_{i t}\right)\end{array}$ & $\begin{array}{l}1.2074 \\
\left(1.48^{*}\right)\end{array}$ & $\begin{array}{l}0.5976 \\
(-0.72)\end{array}$ & $\begin{array}{c}0.9344 \\
(4.39)^{* * *}\end{array}$ & $\begin{array}{c}1.1408 \\
(4.45) * * *\end{array}$ \\
\hline Log Total Employment $\left(\ln t e_{i t}\right)$ & $\begin{array}{l}-0.0877 \\
(-1.40)\end{array}$ & $\begin{array}{c}-0.1595 \\
(-4.12)^{* * *}\end{array}$ & $\begin{array}{c}-0.0975 \\
(-12.06)^{* * *}\end{array}$ & $\begin{array}{c}-0.0758 \\
(-9.53) * * *\end{array}$ \\
\hline
\end{tabular}




\begin{tabular}{|c|c|c|c|c|}
\hline Log Poverty Headcount $\left(\ln p o v_{i t}\right)$ & $\begin{array}{c}-0.1757 \\
(-2.88)^{* * *}\end{array}$ & $\begin{array}{l}0.0147 \\
(-1.04)\end{array}$ & $\begin{array}{c}-0.0519 \\
(-15.74)^{* * *}\end{array}$ & $\begin{array}{c}-0.0431 \\
(-9.31) * * *\end{array}$ \\
\hline Population Growth $\left(p o p_{i t}\right)$ & $\begin{array}{c}0.204 \\
(2.38)^{* * *}\end{array}$ & $\begin{array}{c}0.0945 \\
(1.94)^{* *}\end{array}$ & $\begin{array}{c}0.1031 \\
(7.22)^{* * *}\end{array}$ & $\begin{array}{c}0.1425 \\
(4.68) * * *\end{array}$ \\
\hline 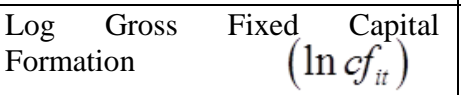 & $\begin{array}{c}0.5338 \\
(1.76)^{* *}\end{array}$ & $\begin{array}{l}0.1726 \\
(1.59)^{*}\end{array}$ & $\begin{array}{l}-0.015 \\
(-0.37)\end{array}$ & $\begin{array}{l}-0.0107 \\
(-0.35)\end{array}$ \\
\hline Log Government Expenditure (ln ge $\left.e_{i t}\right)$ & $\begin{array}{c}-0.79 \\
(-3.14)^{* * *}\end{array}$ & $\begin{array}{c}-0.8311 \\
(-8.45)^{* * *}\end{array}$ & $\begin{array}{c}0.5863 \\
(-11.92)^{* * *}\end{array}$ & $\begin{array}{c}-0.5557 \\
(- \\
16.34)^{* * *}\end{array}$ \\
\hline $\log$ Interaction $\left(\ln f s_{i t} \times \ln l e_{i t}\right)$ & & $\begin{array}{c}0.0687 \\
(3.42)^{* * *}\end{array}$ & & \\
\hline $\begin{array}{l}\qquad\left(\ln f s_{i t} \times \ln t e_{i t}\right) \\
\text { Log Interaction }\end{array}$ & & & $\begin{array}{l}0.0001 \\
(2.15)^{*}\end{array}$ & \\
\hline Log Interaction $\left(\ln f_{s_{i t}} \times \ln p o v_{i t}\right)$ & & & & $\begin{array}{c}-0.0001 \\
(-4.17 * * *)\end{array}$ \\
\hline Intercept $\quad\left(\alpha_{0}\right)$ & $\begin{array}{l}-24.9426 \\
(-2.96)^{* * *}\end{array}$ & $\begin{array}{c}-26.2046 \\
(-7.23 * * *)\end{array}$ & $\begin{array}{c}-26.7535 \\
(-26.16)^{* * *}\end{array}$ & $\begin{array}{c}-29.6614 \\
(- \\
\left.33.45^{* * *}\right) \\
\end{array}$ \\
\hline Observation & 180 & 180 & 180 & 180 \\
\hline Instrument & 79 & 79 & 79 & 79 \\
\hline $\begin{array}{l}\text { Arellano-Bond Test for } \mathrm{AR}(2) \text { in } \\
\text { Differences } \quad(\rho-\text { value })\end{array}$ & 0.854 & 0.571 & 0.878 & 0.879 \\
\hline Hansen Test $(\rho-$ value $)$ & 0.414 & 0.332 & 0.401 & 0.497 \\
\hline
\end{tabular}

Life expectancy at birth is defined by the World Bank as the average number of years a new born infant is expected to live if health and living conditions at the time of its birth remained the same throughout its life. Based on the analysis for the impact of food security on economic growth, this study has found that life expectancy with the condition of food security has a positive impact on economic growth at the 1 per cent level, where a 1 per cent increase in life expectancy with better nutrition intake will increase economic growth at 0.0687 units. This study is supported by Kunze (2013), who states that the increase of life expectancy can raise households' saving rates, increase their physical capital accumulation, and increase economic growth. In addition, an increase in life expectancy will create an older workforce with advanced experience level and a higher level of education, which will help to enhance economic growth (Bloom et al. 2004). Moreover, reduction of the disease environment and improvement of health conditions has increased life expectancy and enhanced economic growth. According to Acemoglu and Johnson (2006), the innovation of the international epidemiological transition with new types of drugs, chemicals, and other international interventions has increased life expectancy; reduced mortality caused by tuberculosis, pneumonia, and malaria; increased population growth; and directly improved economic growth. Moreover, increasing life expectancy as a result of sufficient nutrition intake and sustainable food security will encourage the older population to continue their work if they desire. Working within a year-long period will increase old age worker savings, increase income rate, and generate economic growth.

Next, food security also has an impact on economic growth through poverty channel. Alleviation of poverty with better nutrition can sustain economic growth, especially in dryland developing countries, through several factors such as increasing agricultural investment, creating more jobs, spending on social safety nets, expending nutrition programs, improving education systems, promoting gender equality, and protecting vulnerable countries during crisis. Usually, food security and poverty are inseparable and need to be integrated to enhance 
economic growth in dry-land developing countries. This research has revealed that reduction of poverty with better food security significance at the 10 per cent level has increased economic growth with a coefficient of 0.0001 . This analysis shows that better nutrition can promote healthy lives among the population, better education for children can create better human capital with better skilled workers, and an increase in household income can reduce poverty rate and directly enhance economic growth in dry-land developing countries. This result is supported by a report from the United Nations (2014). Based on this report, increasing the population with a variation on food consumption patterns will increase the demand for food. Sufficiency of availability of food with enough quality and quantity of nutrition will increase productivity of labor, reduce poverty rate, and increase economic growth. Moreover, nutrition is essential to alleviate poverty (Mwaniki, 2006). Food security can improve health and body development, alleviate poverty, and generate economic growth (Cook \& Frank, 2008). Furthermore, Christiaensen et al. (2010) believe that the reduction of poverty, especially in dry-land developing countries, will improve economic growth by increasing the production of the agricultural sector. Agriculture is the best alternative to reduce poverty, because in dry-land developing countries, agricultural sectors provide most of the employment for the household in rural areas so that they can receive their income to reduce poverty and improve their economic growth.

Finally, this study has analysed the impact of total employment with the condition of food security on the economic growth in dry-land developing countries. Generally, the agricultural sector is the largest contributor to the employment of dry-land developing countries. The World Trade Organization (WTO) has endorsed new negotiations on agriculture, allowing dry-land developing countries to re-evaluate and raise tariffs on agriculture products to protect national food security and employment. This study has found that an increase in total employment with the condition of food security has increased economic growth with a coefficient of 0.0001. This study shows that total employment through the food security channel's significance at the 10 per cent level has a positive impact on economic growth. The result of this study has expanded the analysis performed by Braun (1995). The report analysis shows that employment and food security are very important to sustained economic growth. Efficiency in employment will increase household income and raise the ability to access food. In addition, the Food and Agriculture Organization (FAO) has promoted decent work in rural areas, especially in the agricultural sector, to raise nutrition intake, improve productivity on agriculture production, and increase economic growth. Nonetheless, sufficiency regarding nutrition intake will increase employment and productivity of labour. An increase in nutrition and food intake will protect households from dangerous diseases that come with sanitation facility problems. This shows that food security achievement, especially in dry-land developing countries, will increase the ability of people to work as either skilled or unskilled workers. Increasing labour productivity will raise the capital intensity of agriculture production, increase income level, and raise purchasing power parity (PPP). This situation will also assist dry-land developing countries to enhance their economic growth (Strauss, 1985; Deolalikar, 1988). In addition, this research has also adopted three important control variables: government expenditure, capital formation, and population growth. All of these control variables significantly influence economic growth at the 1 per cent, 5 per cent, and 10 per cent levels.

\section{Conclusion and Policy Implication}

Food security has an impact on economic growth, especially in dry-land developing countries. This research has identified that food security has a significant positive impact on food security, as an increase in food security increases economic growth in dry-land 
developing countries. Nonetheless, food security also has an impact on economic growth in terms of life expectancy, total employment, and poverty, whereas life expectancy and total employment with better food security have a positive impact on economic growth, and the reduction in poverty will occur due to better food security enhancing economic growth, especially in developing countries. programs planned to promote food security to enhance economic growth. First, the There are several policies and programs that need to be implemented to improve food security and enhance economic growth. According to the Asian Development Bank (2012), there are three important government needs to provide food-based safety nets and related social protection programs. The aim of this program is to automatically stabilize economic growth to cope with the recent food crisis. In addition, this program is also known to feed the emergency employment program that can offer effective relief through public-private food security funds and crop insurance due to natural hazard shock. The next policy fulfils the government need to enhance the productivity of agriculture through better technology to ensure food security in the long term and to reduce poverty and help to increase economic growth.

\section{References}

Acemoglu, D., \& Johnson, S. (n.d.). Disease and development: The effect of life expectancy on economic growth. BREAD Working Paper (Vol. 120).

Arcand, J.-L. (2001). Undernourishment and economic growth: The efficiency cost of hunger. France.

Areliano, M., \& Boverb, O. (1995). Another look at the instrumental variable estimation of Error Components Models. Journal of Econometrics, 68(1), 29-51.

Arellano, M., \& Bond, S. (1991). Some test of spesification for panel data: Monte Carlo evidence and an aplication to employment equations. Review of Economic Studies, 58, 277-297.

Aschauer, D. A. (1989). Is public expenditure productive? Journal of Monetary Economics, 23(2), 177-200.

Blundell, R., \& Bond, S. (2000). GMM estimation with persistent panel data: An application to production function. Econometric Reviews, 19(3).

Braun, J. Von. (1995). Employment for poverty reduction and food security. Washington DC: International Food Policy Research Institute (IFPRI).

Brumm, H. J. (1996). The human capital augmented Solow model revisited. Applied Economics Letters, 3(11), 711-714.

Christiaensen, L., Demery, L., \& Kuhl, J. (2010). The role of agriculture in poverty reduction. WIDER Working Paper, (36).

Cook, J. T., \& Frank, D. (2008). Development in the United States. New York Academic of Sciences, 16, 1-16.

Correa, H., \& Cummins, G. (1970). Contribution Economic of Nutrition Growth to Economic Growth. The American Journal of Clinical Nutrition, 23, 560-565.

Deolalikar, A. B. (1988). Nutrition and labor productivity in agriculture: Estimates for rural South India. The Review of Economics and Statistics, 70(3), 406-413.

Devarajan, S., Swaroop, V., \& Zou, H. (1996). The composition of public expenditure and economic growth. Journal of Monetary Economics, 37.

FAO. (2002). Crops and Drops: Making the best use of water for agriculture. Rome, Italy.

Gupta, S., Clements, B., Baldacci, E., \& Mulas-Granados, C. (2005). Fiscal policy, expenditure composition, and growth in Low-Income Countries. Journal of International Money and Finance, 24(3), 441-463.

Haddad, L. (2013). Child Growth; Sustainable Economic Growth: What do investments in malnutrition reduction have to do with economic growth? 
Hsies, E., \& Kon S.Lai. (1994). Government spending and economic growth: The G-7 experience. Applied Economics, 26.

Jenkins, J. C., \& Scanlan, S. J. (2011). Food Security in less developed countries, 1970-1990. American Sociological Review, 66(5), 718-744.

Johnson, G. (1997). Agriculture and the Wealth of Nations. The American Economic Review, $87(2)$.

Kinsella, K. G. (1992). Changes in Life expectancy. The American Journal of Clinical Nutrition, 55(6), 11965-12025.

Kunze, L. (2013). Life expectancy and economic growth. Journal of Macroeconomics, 39(April), 1-19.

Miller, J. E., Korenman, S., \& Sjaastad, J. E. (1994). Long-term poverty and child development in the United States: Results from the nlsy.

Mwaniki, A. (2006). Achieving food security in africa: challenges and issues.

OECD. (2008). Growth: building jobs and prosperity in developing.

Ramachandran, P. (2007). Poverty nutrition linkages. Indian Journal of Medical Research, 126(4), 249-261.

Salehi, M., Kimiagar, S. M., Shahbazi, M., Mehrabi, Y., \& Kolahi, a a. (2004). Assessing the impact of nutrition education on growth indices of Iranian nomadic children: An application of a modified beliefs, attitudes, subjective-norms and enabling-factors model. The British Journal of Nutrition, 91(5), 779-787.

Strauss, J. (1985). The impact of improved nutrition on labor productivity and humanresource development : an economic perspective. International Food Policy Research Institute.

Timmer, C. P. (2000). The macro dimensions of food security: economic growth, equitable distribution, and food price stability. Food Policy, 25(3), 283-295.

Timmer, C. P. (2004). Food Security and Economic Growth: an Asian perspective. AsianPasific Economic Literature.

UNEP. (2011). Global Drylands :

United Nation. (2014). The Millennium Development Goals Report 2014. New York.

Walls, H. L., Backholer, K., Proietto, J., \& McNeil, J. J. (2012). Obesity and trends in life expectancy. Journal of Obesity, 2012(1).

World Bank. (2005). Repositioning Nutrition as Central to Development: A Strategy for LArge Scale Action. World Bank. 